\title{
Security implications of alternative defense options for Western Europe
}

\author{
Sørensen, Bent
}

Publication date:

1984

Document Version

Publisher's PDF, also known as Version of record

Citation for published version (APA):

Sørensen, B. (1984). Security implications of alternative defense options for Western Europe. Roskilde Universitet. Tekster fra IMFUFA No. 86 http://milne.ruc.dk/ImfufaTekster/

\section{General rights}

Copyright and moral rights for the publications made accessible in the public portal are retained by the authors and/or other copyright owners and it is a condition of accessing publications that users recognise and abide by the legal requirements associated with these rights.

- Users may download and print one copy of any publication from the public portal for the purpose of private study or research. - You may not further distribute the material or use it for any profit-making activity or commercial gain.

- You may freely distribute the URL identifying the publication in the public portal.

\section{Take down policy}

If you believe that this document breaches copyright please contact rucforsk@kb.dk providing details, and we will remove access to the work immediately and investigate your claim. 


\section{TEKST NR 86}

1984

SECURITY IMPLICATIONS OF ALTERNATIVE DEFENSE OPTIONS

FOR WESTERN EUROPE

Peace research series no. 2

af Bent Sørensen

TEKSTER fra 
SECURITY IMPLICATIONS OF ALTERNATIVE DEFENSE OPTIONS FOR WESTERN EUROPE PEACE RESEARCH: SERIES No. 2

af Bent Sorensen

IMFUFA tekst $\mathrm{nr} .86 / 84$, RUC.

33 sider.

ISSN $\quad 0106-6242$

West European security implicstions of five zlternative defense scenarios are assessed for the period 1995 to 2000. The main chargcteriatics of the five scenarios, one by one, are 1) eurrent nuclear and conventional posture, 2) $A$ submarine based, West Eiropean strategite nucleap force, no tactical or land-based nuelear wapons but current conventional posture, 3) Same as 2) as regards nuelear posture, but a high-techrology area defense with low mobility, 4) No nueleap weapons at all, territorial high-technology defense of some mobility, and 5) Ho military defense, but defense budget spent on international conflict prevention.

Security is appraised with repect to nuclear destruction and with respect to foreign occupation. Scenario 1 is found to lower security against nuclear destruction, scenario 4 is stable in this respect, and the remining scenarios increase security. As for territorial accupation, scenario 4 is again stable, while all the other scenarios except number 5 improve security. These estimates are based on the assumption, that western Europe carries through its alterrative defense policy unilaterally. frms contral agreements with potential aggressors could improve security under scenarios 3,4 and 3. 
The purpose of this papen is to assess the relative changes in West Europexr seciumity resulting from a rumber of alternative defense policy implementations. Each will be described in terms of 3 defense planning and the corresponding set of political actions which will gradually change the defense posture from the present one into the " "goal scenario" for each altermative.

First I give a brief description of exch goal scenario and the path leading to it. The time frame is typically to the end of the century, but some of the scenarios may take more time to implement. After having presented the scenarios, their security implications are discussed and compared.

\section{SCENFRID 1}

The first scenario is the outcome of current defense plarining. It basically rests on g. nuclear plus conventional and possibly a chemical-tiological force posture, each having many comporients trat differ in use and purpose. The aim 1 is to be able to face up to any aggression or combination of aggressions with a messured response and the ability to control escalation step by step.

The frameisork for this force posture is a military allignes, NATO, iskigh makes 1 t posslule for 1 ts West Eumopean members to supply assistance to exch other in case one $1 \mathrm{~s}$ attacked, and to Involve the United States from the beginining of a confliet, through its forces and weapons deployed in hestern Europe, and later through reinforcement programmes:

A wide range of ruglear weapons, and possibly also some 
chemical ones, are stored in Western Europe. Some belong to the esuntry ishere they are stored, but many ane bwned by the United states. These inelude bittlefield ueapons, tactical and semi-strategle misslles, airmatriched tombs and a number of strategic weapons.

The final step of escalation might inisulve the strategic leapons in the united states or on their strategic bombers and submarines.

The presert arsenal of nuclear miseile warheads for use in a Eumopean confliet is distplbuted cin three kinds of launish platforms: ground-based ones (fixed or mobile', aim-based ones (bomb on missile earpying planes) and sex-based ones (rotably submarines). Table I gives a summary of the distribution of all nuelear uspreads on launch platforms and ranges. The range is taken as the combined range of earpier and missile.

A substantial corwentioral army, naby and air force is kept in Western Europe, with emphasis on combat airerafta, helicopters and artillery with d. uariety of short range missiles, and comprising a large number of trained soldiers (Table I).

The current threat perception involvas an inisasion by the Soviet Jnior and its Warsaw Pact allies. Such an invasion is to be met at first by a "forward defense", that 1 s one will attempit to stop the eriemy at the borders and preferably on his side. Tactical weaporis will be used if the enemy makes too much progress, or if he uses them, and strategic nuclear weapons will be used, when it is judged that an acceptable settlement carnot be reached by letting the "theater war" continue. 
As the Soviet Union continuss to improve its force posture by introdueing more reliatle and more controllable weapons and Earriers, the West European defense planing is seen as inevitably involwing the same steps. Fbove that, it should make use of hestern superionity in electronic technology to accelerate the sophistication of neld weapons and control systems ctarget analysis and homing devices, automatization of battlsfield analysis and command iristructions). The result is expected to be the ability to detect eremy actions far behird the front lines and to presmptively attack second and thind echelon forces, aimfields, etc. ("deep strike"):

Although the main requirements for this type of defense development is in the intelligence gathering and real-time analyais fields (Fnon., 1984a), it is also experted that new types of military hardware will be nesded: Multiple launch systems for tactical use (Feazel, 1984), intermediate range Pershing-2 missiles (a few of which alresdy deployed), long rarige ground launched cruise missiles, doditional submarines for French and British forces, new French submarine launched ballistle missiles $(M-4)$ and stepwise modernization of British submarine launched miseiles cheyaline system and later the Trident-1 and -2 also used by U.S. submarines) (SIPRI, 1983), new tactical airerafts (in france Mirage 2000M, in the U.K. Sea-Hamplens and intermediate range fighter-bombers with improved missile equipment (In France RSMP arid later 15 missiles deployed on a reduesd number of Mirzge-4 planes, presently carrying free-fall nuslear bombs, in the U.K. replacement of Buscaneer fighter-bombers by Tornadoes - missile equipment not disclosed). The U.S. is 
going to deploy mome cruise missiles on aiperafts CArkin et a., 19843 and ships, and it will build new ground launched missiles (the PW missile), B-1 bombers and later the ATB plane with "stesith" eapability. flong with this dewelopment, command and eontrol systems will be highly improved, using very large seale integraterd circuits for real-time friend or foe identification. target imaging and aubmarine detection. and hamdening fommand and eantrol centers agalnst electromagnetic pulsas arid missile attacks. Furthermore, consideration is given to missile defense systens such as hypersonic interceptor missiles and later space lauriched boost-phase interieptors ifnon. 1984b: Rdsms, 1983; Mormison, 1984; Robinson, 1384; Garuin et al., 1384; Arkin, 1983).

The Souiet Union is responding to the MATU build-up by forisand deployment of $55-21 / 22 / 23$ missiles in East European neighbour souritries, by introdueing intereeptor airplaries (MIG-31) with special "anti deep stpike" capabilities (Anon., 19345), and by inereasing the number of (3U-24) fighter-bombers and attack helicopters. With respect to misstle defense and space uar techmologies, the soviet Union may have a 1-2 year lead over the united states. The current Sovist command and control system is fairly vilnerable, but it could be improwed, for example by moulrig CC satellites to nigher orbits.

It is evident, that this "business as usual" scenanio does not have any "endpoint". It is a model of a continued arms race encompassing all technology fronts. Scenario 1 is the military equivalent of the "unlimitgd economic growth" paradigm wellknown from sorial debates in the 1970ies. The 
basic philosophy behind scerario 1 is that "we" must demonstrate our ability to fight trirough any type of war, including nuclear wars.

SCEMARIO 2

The second scenario is centered around the (re-)iritroduction of the deterrence strategy. The deterrerice of a potential aggressor would result from possession of mearis to achieve. A) assured destruction of his leadership, and $B$ ) the infliction of unacceptable damage to his society at large.

The threat gainst enemy leadership is important because it is the leadership that decides to effectuate the aggression. It should know that leaders will be the first to 90. In order to assure this, a substantial number of wery destructive weapons must be directed at any conceivable locale of eremig leadership cuith multiple targeting of each location). The threat of inflicting unacceptable damage could te based upon high-yield ruclear armed missiles targsted at population eenters (as in the late 19501es).

Ho ficilities for fighting protracted, limited or tactical ruelear wars are needed in this scenario. Themefore the nuclear arsenals ean be grextly reduced. Western Europe bould get rid of all .land-based nuelear arms (including those owned by the United States), and it wald be natural to restrict the determerit nuclear force to long-range sutumarine-lajurhed ballistic missiles. This is because the addition of air-laurehed ballistic missiles con alremafts of which a certain flegt would always have to be airborne) would inake support airports abulous targets for attempted 
preemptive strikes. An assessment of the development in relative whlnerability of bomber planes and submarines would from time to time be used to decide whether both are needed or not. At present it would seem that the advantage of only possessing submarine-based nuelear arme by far outweights any doubts on the development of relative ulnemability over the rext 19-15 bejers.

A eentain corventional foree has to be retained in Westem Europe, in order to make sure that orly massive assaults may lead to the release of the deternent wespons. Scenario 2 simply assumes that the curpent corventiond army is kept, but that its nuclear components are removed. This would have little organizatorial effect, because the army is already trained to conduct a conventional war through all its phases, in case the eonditions for nuelear escalation remain urisatisfied.

It does not matter for this sceriario, whith policy the Warsaw Pact pursues. If the enemy launches an attack which does not appear to be containable by use of liest European converitional forres. or if the enemy uses any nuclear (perhaps extended to chemical/biologieal) weapons, then the full-scale ruclear retaliation will be released. It is this automatic full-step escalation which constitutes the core of determence.

Scenario 2 does not foresee any need for an increase in conventional strerigth as long as the ultimate deterrent is still ruclear. It would be natural to accompany scenario 2 with a. West European pledge not to attack any Warsaw Pact member.

It has for some time been clear, that the United 3tates 
uould not use U.S. based strategic nuclear arms against the Soviet Union after a Soviet attark solely directed at Western Europe (Douglass, 1980, p. 188; Kissinger, 1979) ${ }^{1}$. In line with scenario 1, the U.s. may in such a situation use its European based inuclear weapors in an attempt to limit a nuclear war to Europe. Since the arsenal deployed in Western Europe at present and according to scenario 1 planning coritains inereasing numbers of intermediate and long range missiles, it would become very difficult for West European political leaders to control the situation. Only if the Soviet Union attacka the U.S. mainland will full strategic retaliation be relessed.

In the light of these observations, and because scenario 2 specifleally calls for removal of all U.S. nuclear weapons from Western Europe, then the 3trategie nuclear deterrence force described will have to be West European. The scenario thus involves an INDEPEHDENT HEST EUROPEAN STRATEGIC NUCLEFR. FDRCE (ISNF).

This force must have sufficlent strerigth to deter, and should be folntly operated by the West European nations cor at least several of them). In scenario 2 , it would not make sense for presently nom-nuclear Europesn nations such as Denmark not to be co-owner of this force, once it is purely West European and orice all tactical and land-based nuclear weapons have been remoised.

\section{SCENFPIO 3}

This scenarlo is the same as scenario 2 as far as the nuclear policy concerns, that is it involves an independent strategic ruclear force (ISNF) owred and controlled jointly 
by the Hest European countries for the purpose of deterning. Howewer, the eorisentional defense is modified from the present "forward defense", which in scenario 1 develops into a. "deep strike defense", to a "ternitorial defense".

F number of territorial defense postures for Western Europe have been discusesd ${ }^{2}$. The variety erisisaging a fire-barrier forward defense is not considered here, because it would allow the enemy to resch grywhere within the fire-barrier confinement by using existing missile systems of suitable range. Seerario 3 rather assumes an "area. deferise" with decentrgilized units of modest mobility.

In prineiple, an "greg defense" coldd be highly mobile as well as totally non-mobile. Vehicles of mobility could comprise bicycles, motorcycles and light trucks, the latter allowing for light missile transport. Precision guided munition ("PGM", Walker, 19a1) plays a very important role in all territorial defense scenarios. It is to be used against aipplanes as well as against tanks. PGM launch platforms are normally motile but could 3 lso be fixed and remotely controlled. Some PGM weapons may be handheld.

The argument put forward by Fgrell (1384), that terpitorial deferise must be centrally controlled and therefore involve wulnerable command arid control sites, is probably too peseimistic. The subterranean electronic highway system clight guides and cables allowing d. very high density of information to be transmitted), which 13 cummently installed or being installed in most West European countries, could aerive s.s a wartime communication system with lots of meduridaney and substantigl iniduerability. It lupld therefore allou lesdership and control to be highly 
decentralized arid diffleult to target, and would yet allow full aross-communication and coriduction of well-coordinated setions.

In order to ensure independence in 1ts decisions, Western Eumope must itself master the technology it uses. Thus both the new conwentional techrology cfor POM weaporis and electronic command and control systems and the strategie nurlear technology (for the ISNF) must be in the hands of the West European countries. This means decoupling Western Eumope from the technological arms race betueen the United States and the soviet Union, which stretches into many areas Irrelevant to a Western Europe followirig scenario 2. Hestern Europe need not follow the United States space inar efforts, and it maly develop electronic concepts and devices more eompatible with the European scene and the requirements of an ares. defense, as distinet from 1.3 . technology, which is meant to serise purposes outside Europe and hence may have different design featidres.

The reasons for replacing the eonventiorial type of defense by an area defense is to remove any offensive posture and to eliminate targets iriviting for highly destructive (nuelear) warhead use. This is the reason for not wanting to make the territoris.l defense too highly mobile, in which case it could be wiewed by the enemy as an instrument for attack. If the defense were totally stationary, it would exhibit some vulnerability, although a misaile attack on all sites knourn to the enemy would come elose to a total destruction of the area. Scenario 3 assumes some mobility (such as bikes or motorbikes), in order to obtair maximum flexibility without appearing offensive. 
The scenario can te approached unilaterally by bestern Europe. Should the Sorsiet Union stapt use of ruclear weapors, the ISNF will become released similarly if the Soviet Union becomes unacceptably "succossful" in a conventional attack. The ultimate deterrent role of the ISNF lends the area defense a eredibility nullifying the usidal emiticism (Iankbaar, 1384) of inefficiency against a blunt nuelear attack by the Sowiet Undon.

\section{SCENPRIO 4}

Scenario 4 consists of a terpitorial deferise for Western Europe, without any nuclear component, that is without the strategic nuslear foree of seenamios 2 and 3.

The territorial defense will have to be more mobile than in scenario 3 , because it should be able to throw an enemy back - out of the territory. There is no nuclear deterrence that car be used iri regoriating an end to a conflict, and therefore trie corventional territorial force must hawe some offenstve capsbilities, although the range of possible actions should be kept as lo $3 . s$ fossible, in order to retain the adiantages of rot threathening the potential enemies in wajs which could fuel din arms race.

The territorial force of sesnario 4 has to be complemented by a "super flull defense" eapable of staging eivil disobedienee campaigns and guemilla warfare. There may be a emooth connection betueen the territorial defence and the civil defense, which would be operating once the enemy has gained possession of the territory. The territorial deferise would comprise F'GM we g.pons and adianced electronics, 
e.g. ineluding automated battefield concepts.

It would seem that the Dankbaar (1984) eritielsm of territorial defense concepts would be walid for scenario 4: The enemy could sit at a. safe distance and fire ruclear missiles until the civil population and political leaders has had enough and submits to any coerciue demarids from the enemb. Thus proponents of scenario 4 luill have to deal with foreign oecupation and ways of responding to it.

\section{SCENARIO 5}

The final scenario presented is one based on a non-military deferies. It plans in the evert of a foreign aggression to forus on ways of reacting to foreign oceupation, by civil disobedience and possibly by guerilla activity.

The main content of the scenario is an effort directed at the causes of war, and it proposes to spend the money saved by not having a military defense on international conflict prevention. This could be in the form of asslstance to regisins with social problems, and by undertaking an initiating role in promoting better understanding and furthering negociations tetween the superpousers and any aggressive regimes or mo'fements of international relevance.

Sanctions in the form of political and economic pressures could be used against rations unwilling to move in peaceful direstions. Historical arralysis does rot warrant much optimism regarding this approach, but it is conceivable that indiuidual rations or groups of nations embarking on missions of conflict prevention will ir return receive some goordull and along with it a reduced tharee of falling 
wictims to foreign aggression. Some weuld argue that on the contrary, lack of a military defense will inwite aggression against counitries mowing towards scenario 5.

Could one imagine all of Westerr Europe becoming a demilitarized region? The closest example is that of Japan, which for a number of years has been more or less demilitarized. However, Japan has a defense guarantee from the United States, ishich is presently taking advantage of the militarly deperidency of Japan to influence Japanese deferise policy cincledentally in the direction away from the prewious non-military postures.

Western Europe does not have any effective nuclear guarantee from the United states, and it isould presumably lose its conventional reinforcement agreement with the U.S., in rase it went in the direction of demilitarization. Scenario 5 would truls inulve 2 substantial disconnertion of Hestern Europe from the foreign pollay of the United states. This luould have the positive effect of disengaging Western Europe from the 1deologieal struggle of the U.S. against communism and often everi against social demoeracies. Few people in Europe share J.S. wieus on these matters. On the other hand, the actual danger of ldeological crusades by the Sowiet Inion in fawor of its style of communism might increase if Hestern Eurape were to become demilitarized.

Would a chosen "Finlandization" of all of Western Europe induce the Sowiet Union to use political coersion based on military threats against such a Western Europe without military deferise, and would the probability of actual inwasion increase? In the case of finland this has not happened, but this may have something to do with the 
preveritive effect of West Eupopean and U.S. opinion. If all of Western Europe chose scenar1o 5, 3. "world opinion" would hisue to be motilized in order to possibly influence the aggressor.

Fnyugly, scenario 5 accepts the possibility of an inwasion, considering it a miror eivil than a destructive (nuclear) war. A number of options remain after an invasion. renderirg it almost certain that the period of foreign orcupation will be finite although painfijl.

\section{AESE:SIMG WEST EURDFERM}

\section{SELURIT'י FDF EFICH DEFEMCE}

\section{PLTEFHFT I 'PE}

For each of the flve scenarios and the defence policies leading towards their implementation, the risk pieture will have to be assessed. I do this in terms of two quantities: the enemy eapability and his intentions. The enemig expobility deperids on his offensive strergth and on our sbility to zisert ggaressions by militiry defense or other mesns. The enemy intentions clearly depend on the force posture and deferise poling shosen by our aide.

The product of Enemy capability and intentions as defined aboue is a mexsure of the risk of aggression. It can be estimated for differert kinds of aggression, such as destructive (ruelear) war ard territorial occupation. One divided by the produrt of eremig eapability and intentions is 1. measure of our Eecurity. The smaller the $r i s k$, the hlgher the level of security. If the risk is messured per unit of time rasy per year), then the quantity identified with security may be interpreted as an estimate of the time span 
(years) between assaults, pertaining to a given moment in time (Somensen. 1974). Changes in security ean thus be estimated as function of time.

The uncertainty associated with quantitative estimates of enemy capability and in particular of enemy intentions is large, and the present analysis shall be restricted to relative comparison of the differert scenarios. Howewer, the use of numbers and curves is considered useful in order to keep track of the many elemerits of asemesment needed for evaluating five alternatives ower a time span of 15 years, and with respect to both nuclear destruction and foreign occupation. The graphe presented give an oweruiew difficult to eonwey in words. Wet the warning must be given, that the use of numbers does not imply any lamger accuracy than that contained in the verbal and by necesalty subjective formulations.

\section{SCEHARIO 1}

The capaliility of the Sowiet union to destroy Western Europe is rear 190\%. Little can be done in terms of defense. in Ease a large-scale nuclear luar is launched. Soviet nuclear capabilities are lnereasing, but tris makes little difference, as the destructive capability is already rear total. The interitiors of the sowiet union to engage in nuelear war is judged as small but inereasing, because of the NATO armament envisaged in seenario 1 . The soviet is inereasingly disturbed over new Euromissiles with range enating a deep penetration into souiet territory, and it "iews current U.S. polify as aggressive. If the Soviet Union believes itself threatened to an extent that in the view of Soviet leardership makes idar inevitable, then it is likely to 
go for the advantage of seizing the iritiative (Douglass, 1980). If war in Europe appears unavoidable, the Soviet Union is not likely to move in terms of the stepwise escalation envisaged by NATO defense plans because that bould give the West all the advantages), but rather it will laurich a. full-scale nuclear attaik on all targets in Western Europe considered important for military, industrial or leadership purposes. Dnly assets deemed useful to the sowiet Union (e.g. agricultural land) may be spared. Thius the scenario 1 build-up of Western nuclear and other advanced technological forces will continue to inerease the risk of a destructive attack by the sowiet union.

This could be changed only if Hestemn Europe obtained a missile defense with demonstrated eapabilities, or if the United states gained a permarent superiarity in space. Hone of these propositioris are werly. likely, and not at all before yexr 2990.

FE for Soviet orcupation of bestern Europe, the military capability of carrying through such sin eccupation is modest and declining, as the HATO conventional and nuclear arms are improused continually in qualitig and uersatility. Also the intentions of the soulet Union to oceupy Western Europe are small, probably corisiderably smaller. that the sowlet belief that it might become plaserd in a situation where nuclear war in Europe could rot be awoideds. In any case, the type of Western deferiee possessed today and expanded upon in scenario 1 makes it practically eertalri, that large numbers of riuclear and other highly destructive ueapons will be used in a. confliet arisirg from a. s.l. attempt to invade arid oreupy West European termitory. Thus the benefits that could 
be derived from possession of that territory after a war would be minimal, and sowiet intentions regarding occupation are assumed to diminish between 1985 and 2090 , while the risk of hawing to engage in a large-scale ruclear war against Western Eumope is lnereasing. The assumed dewelopment of the misk parameters fom nuelear destruction and foreign occupstion are showm in Figs. 1 and 2 , song with the implied messure of securityd both for this reference scerario and for the alternatives to be presented be low.

\section{SCENARIO 2}

The enemy capabilities for nuclear destruction and occupation of Western Europe are the same for this scenario a.s for scenario 1 , because the new iridependent strategle nuelear force in Western Europe is assumed to influence the intentions not the capability of the Soviet Union, and because the corventional forces are identical to those of sceriamio 1.

The phasing out of land-based and 1 . S. owned nuclear. weapons in Western Europe is assumed to take place from the late 1980ies to the mid-1990ies. It immedidely lead to a decline in soviet lntentions for a destructive ruclear crusade against Western'Europe, because the rationale for such intentions (as preserited above) would disappear. The aggrossive intentions reach a low and stable level, once the West Europezin nuclear deterrent is in place.

The Soulet intentions for invasion and occupation 'decrosee more rapidly than in scenario 1 , because the coriweritional force remainimg is seen as lisss offensive than 
the one inwolving intermediate and long range nuclear weapons. Folitical tensions between bestern Europe and the Sowlet Unior are reduced in this scenario, because the main reasons for them are removed, and the slight increase in chances of being suresessful in an attempted sccupation of Western Europe (without nulelear ugapons) is not sufficient to turn the trend. The model assumption, that the year 2000 Soviet intentions of oceupation are higher than those of nuclear assault, reflects the possitility that $3 . U$. leadership may think that Western Europe would after all not use its nuclear force in response to a conventional force invasion. The opposite clase that Western Europe would attack the Sowiet. Union by using its conventional forces, or would mix into East European affairs, should be sufficiently deterred by the souiet nuclear areenal. SCEMARID 3

The nuclear destruction part of this scenario is the same 3.s for scenario 2. Howluger, the lack of offensive components in the West European territorial defense should make the Sowiet Union more secure. The initial reaction to this is seen as a reduction in Sowiet intentions for invasion and oceupation (relative to those in scenario 2). Towards the end of the century, the Sowiat Inion may percelve shances of suresesful political Ebercion or territarial invasion as being higher, with a somelwhat higher level of intentions 3.8 a consequance (still relative to those of scenario 2).

The reduction in. Sowiet ability to carmy through an inuzaion and territorial ofeupation of hestern Europe, which $i$ s the atandard sernario $i$ s brought about by the arms race, is not found in scenario 3. Fither: the territorial defense 
would attempt to $3 t o p$ an attack oleeper 1 into West European territory, and the risk that the inusion may not be stopped is higher. This in itself would indicate some increase in sowlet eapability relative to that of 1985 , but it may be compensated for by the edge in use of sodvanced technology held by the Western countries and sssijmed to become fuily exploited in their ares. defense. The pesult of these considerations is that "the byerall soviet eapability for getting into and aceupying West European terpitory will remain at the 1985 level.

\section{SCENARID 4}

Since scenario 4 does not comprise any nuelear deterrent, the Soviet intentions of a nuclear attack are not reduced as much as in scerario 2 or 3 , and the capability of destmuction becomes ewen more ertain. The probability that the Sowiet Union would want an extented destruction of Western Europe is small, but use of Souiet nuclear weaporis in a limited war in Western Europe would be enhanced by the absence of such lueapons on the Western side.

The initizl reartion of the Soulet Union, if the West European countries were to ain at Ecenario 4 , would presumably be one of goodsill, reducing the intentions of both nuclear destruction and of territorial assault. However, the nuclear intentions are then assumed to stay constant for the reasons given abowe, and the intentions for an oecupation maly begin to mise, because the soviet Union could envisage an inwason not employing nuelear weapons and thius making the ares. murh more useful to the soviet union once occupied. The rise in Boviet intentions for accupying 
Western Europe after: 1999 has been taken as modest, assuming that world opinion would make such an irwasion unpalatable. Should the geopolitical situation change, there could be room for a more $\equiv i z a b l$ increase.

\section{SCEHRRIO 5}

In this scenario, the Soviet intentions for nuclear. destruetion of Western Europe drops at least as much as in scenario 2 or 3 , because the purpose of such destruction is totally absent for a region without ary military defense. The pace of reduced intentions is given by the time needed to actually demilitarize bestern Europe. A proloriged trariaition time is assumed for redsons becoming clear below.

The Soviet ability to invade and oceuply elearly rises, as best European diadrmament progresses. The intentions are zesumed to first dimirish as a result of goodwill, but then to inerease due to the temptation presented by a defenseless Hesterr Europe. Houever, this irierease has to be modest, becaluse if it bere rot, West European countries would surely rewert their decision to fol low scenario 5 . If the fruits of spending deferise morrey on conflist pueverition de not show, then West Europesin poliey luould Ehange, so even if the Sowiet Union did rave bad interitions. it would be wise not to show them openly. What could happen 1 s a rapid shange in Sowiet intentions, for instance connected with leadership shange. This could make the risk of a successful invasion of Western Europe iery high, becaluse the nori-military posture eould rape been made complete during a prewious period of benevalent. Soujet leardership. This angument against demilitarization, which may be ealled the "madman theory", 
has been very popular since the case of Hitler. The reality is of coumse, that the combination of conflict aversion and non-military defense is thirkable only in combination with the will to endure a period of foreign occupation, and with plans for resistance against an occupting force. The possibility of occupation is the price being payed in this Ecenario for lowering the risk, of nuclear destruction.

\section{PEMARKS ON COST OF DEFEHSE}

Without engaging in a proper cost estimation for the five scenarios, a brief look at costs will be made in order to ascertain that no alterrative is completely off the board for purely economic reasoris.

The reference seenario will entall pising eosts in real terma. The "deep strike" eapability ras been estimated to require between 29 and 199 tillion eurrent U.S. dollars over 3. period of about six years ${ }^{3}$. This is followed by costly programmes of missile defense and space war. It is therefore a. louser limit to assume average Hest European defense budgets to increase by 2 pet. annually in real terms, throughout the period 1985-2000. The United statea defense budget will have to increase even more in this scenario.

It is clear that defense expenges eannot indefinitely inemease in real terms, and this is one inherent ineoriaisteriey of seenario 1.

In scenario 2, the West European ISWF has to be payed for, and notably the increased number of sutmarines rieeded. Holdeyer, the increase may be compensated for by the savings obtained by not having to maintain strategic planes or to retain or rerew any kind of tactical nuclear arms in Western Europe. The cost of the corventional force is the largest 
comporent of the budget, and it is the same as in scenamio 1, because it is the sme force. The total cost profile of scenario 2 may thus be taken as ideritical to that of scenarto 1.

The area deferise of acenario 3 may exhibit some savings relative to the conventional force of scenarios 1 and 2 , but no zecurate estimate can be made (Brauch and Unterseher, 19843. There is hope that the cost of the territorial defense does not escalate with time, and so the total west Eumopean defense budget may stay constant after a transition period (ending sround 1995 ).

In scenario 4, the cost of the ISHF is absent, but the more mobile territorial defense might cost more than that of acenario 3. The stabilization of total costs may occur sooner than for scenario 3 , pertias already bu 1990.

Finally, seenario 5 by definition uses the same defense budget for conflict provention and civil defense, which bould otherwise have been used far military defense. The total cost may thus be taker as the same as for scenario 4.

A more detailed cost evaluation for the components entering the different scenarios would be useful, but one should rememuer that most estimates of the costs of future technologies are blased, either upwards (by opponents) or dounwards (by proponents).

The remarks made here suggest, that scenarios 3 to 5 are economically feasible as long-term solutions, while scenario 1 arid 2 have a trarisitional nature, because the contirued inereses in real term costs canmot go on indefinitely. After year 2009, if not before, scenario 1 and 2 would have to change direction in order to become realistie proposals. 


\section{CardClusi I IH}

The appraisal of the five West European defense scenarios in temms of a messure of secumity against ruclear. destruction and foreign occupstion is summarized in the lober parts of Figs. 1 and 2 . The importance of alternative defenes views is elear from the primary deficiency of cumrent military deselopment: Although security against Soviet oecupation is improved with time, this is paid for by 3. steady decline in security against nuclear destruction.

The most radical alternative, scenario 5, leads to increased security with respect to ruelear destruction, but at the expense of security against inwasion and foreign occupation. Scenamio 4 leads to approximately stable levels of security in both cases, while scenarios 2 and 3 improves safety both related to nuclear assault and to occupation by the sowiet Urion.

The coriclusion is then, that alternatiue defense policies involwing the remowal of all land-based and tactical nuclear arms from Western Europe should be seriously studied. The measurea have the aduantage not to require reciprocity from the Warsaw fact members, and of the two options for a conventional defense. the one not requiring any great modifications of current planning would seem easiest to acespt in the short term. That also mesns that the NaTo allince can continue to exist and have a defense role similar to the present ore, 3.5 far as converitional forces are concerned. The remoual of U.S. nuclear arms from Europe, and the expansion of the indigenous strategic ruclear. 
deterrent spresently eonsisting of 30 French MSES M-20 missiles with 1 lit warheads on 5 subnarines and 64 British Polanis R-3 missiles Earrying 3 times $260 \mathrm{kt}$ warheads, on 4 submarines) will entail some rewision of HaT0 dortrines, but primarily it will bring formal melations between Western Europe and the Inited states in better accordance with realities.

It $i \equiv$ important to stress, that the diacussion above cannet be used to rule out scerarios 3 to 5 or 4 to 5 . The political assessment of these scenarlos should consider a rarige of social impacts other than nationsl security. For example, the international improvement of economic relations that might result from following scenario 5 could outweight the decrease in security against occupation. The relative weights of ruclear and territorial assaults in security assessments should be discussed. There is also the question of negociated arms reduetions. All the acenario Eualuations made above have yssumed the measurea to be unilateral. If the Souiet Union and its allies would agree tio make similar reductions and ultimately to remove all nuclear arms and offeriside corweritional weapors, then the advantages offered by scenarios 3,4 and 5 would greatly inerease. 


\section{HDTES}

1. Public attitudes in the United States support this poliey (Kramer et al. 1983. p. 14)

2. See e.g. 3ummaries by Jankbadr (1984), Eraluch and Unterseher (1984) and Barnaby and Boeker (1982)

3. The lower figure is from European Security study (1983), the righer ore from Weiner, as quoted by Brach and Unterseher (1584) 


\section{FEFEFEHCE:}

Rdams, Bordon 1983. Congress begins the debate. The Eulletin of the Atomic Seifntists, Fipril, wol. 39:4, pp. 25-27

Rgrell, Wilhelm 1384. Small is not besutifill. Journal of Peace Research, wol. $21: 2$, pp. 157-167

Anonymous 1994a. MBB presses laser, sensor research. Awiation Week \& Space Technology, May 21, pp. 193-110

Finonymous 1984b. Hew circuits expected to exceed projections. Puiztion Heek \& Space Terhrology, July 30, pp. $46-61$

Fnonymous 1384e. Sowiets reequip forluard air forces. Auiation Week \& Space Technology, May 21, pp. 65-72

Frkin, William 1383. Souiet Cruise Missile Programs. Frms Control Todaly, May, F.j. 3-4

Arkin, H., T. Cochrar \& M. Hoenig 1984. Resource paper on the U.s. Nuclear Rrsenal. The Bulletin of the ftomic Selentists, vol. $40: 7$, Fp. $3 \equiv-155$

Barnaby, Frank \& Egbert Bosker. 1982. Defense without Dffence. London: Houssmans

Bepr. Franeis 1931. Fesce against War. San Francisco: Freeman \& Co. 
Brauch. Hans G. \& Lutz Unterseher 1984. Betting rid of nuelear weapons: A review of a few proposals for a. conventional defense of Europe. Soupnal of Peace Research, vol. $21: 2$, fp. 193-199

Dankba.ar, Een 1984. Flternative defence polifies and the peace movement. Journal of Peace Reseameh, uol. $21: 2$, pp. $141-155$

Jouglass, Joseph 1980. Sowiet Military Strategy in Europe. Hew York: Fergamon Press

European Security Study 1983. Strengthening Corventional Deterrence in Europe. London: MacMillan Press

Feazel, Michael 1984. Hato ratifies selection of emerging technologies. Fuiation Week a Space Technology, May 21, pp. $26-27$

Gamin, R., K. Gottfried \& D. Hafner 1384. Fintisatel lite Weapors. Scientific American, Iune, vol. 259:4, pp. 27-37

Joffe, Josef: ed. 1981. Friede ohre Waffen? Munchen: Wi thelm Heyne

Kissinger, Herry 1973. HATO Deferise ard the Eoviet Threat. suruival, How./Der., p. $2 E \epsilon$

Kramer, E., S. Kalick \& M. Milburn 1383. Fttitudes towards 
Huclear. Heapone and Hijelear War: 1945-1982. Journal of Sorial Issues, wol. $39: 1, \mathrm{pp} .7-24$

Lunn. Simon 1982. Ft issue: nuElear modernization in Europe. The Bulletin of the ftomic Scientista, vol. 38:7, pp. 17-23

Mormison, Dauid 1984. Air-breatring nuclear deliwery systems. The Bulletin of the ftomic Sclentists, wol. 49:2, pp. 32-39

oberg, Jan 1381. Myter om wor sikkerhed. Copenhagen: Mel lemfolkelig Samuinke

Paxton, Jokn, ed. 1980. The Statesman's Year-book. Berlin: Walter de Grulyter

Robinson, Clarence 1984. U.S. rewelops antitactical weapon for Europe mole. Fuiation Heek \& Esace Technology, April 3 , Pp. $46-43$

SIPRI Yearbook 1982, 1983. World Frmaments and Disarmamert. London: Taylor arid Franeis

Somerisen, Bert 1984. On the quantification of Security. IMFIJFA Text ro. 83, Roskilde University Center

Tromp, H. \& 0. La Roeque, Eds. 1382. NuElear War in Europe. Bronirigen Iriduersity Press

Halker, Faul 1961. Frecision-guided Weapons. Ecientific 
American, Flugust, wol. 245:2, pp. 21-29 
THELE I

FFEEER-HT FDFCE FIRTILEE

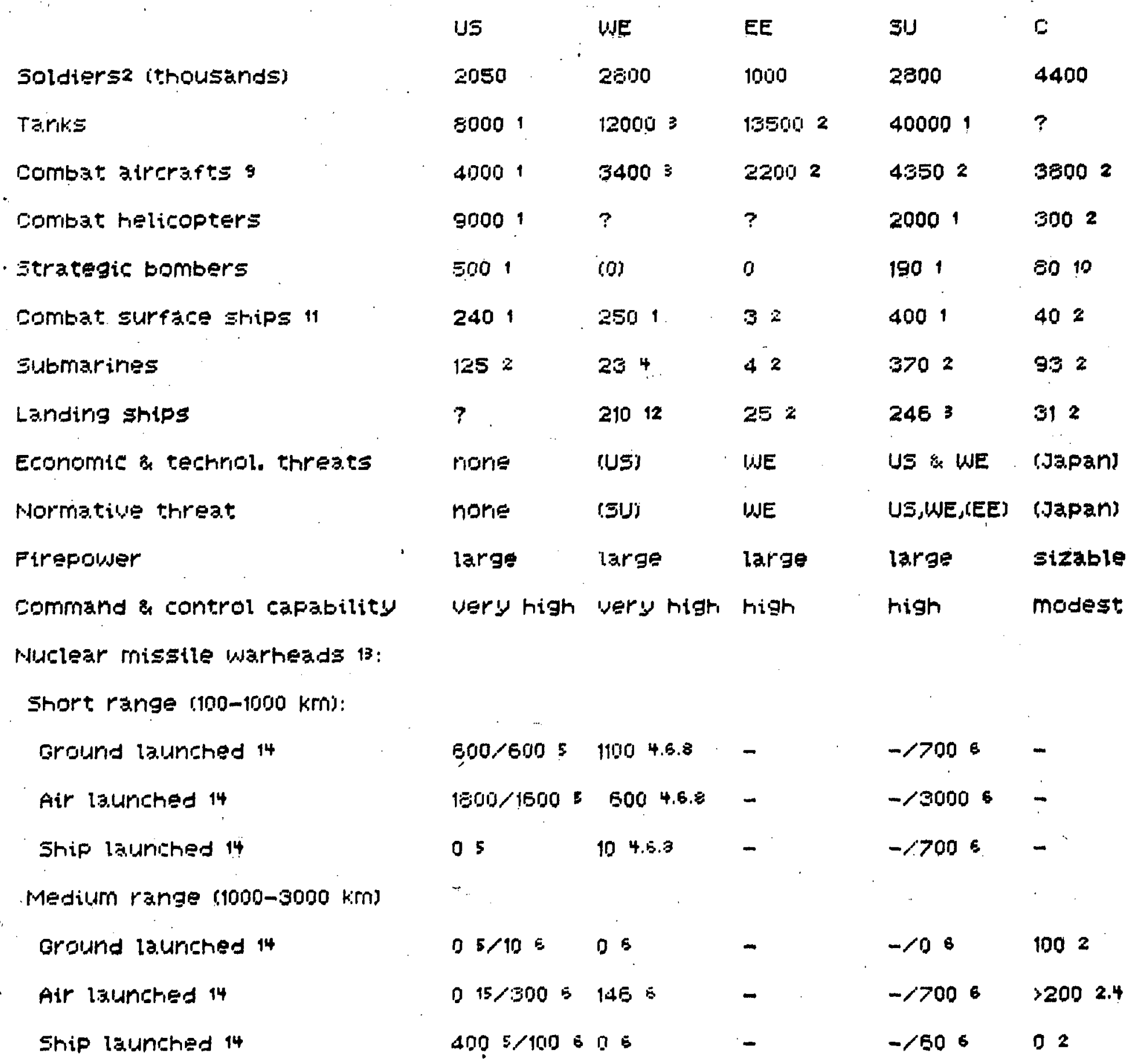

Lomg range (; 3000 kirm)

Ciround latdrened 94

Gir lalunched 14

Shtp lisunched 14

Ehemira.l u.japons $15^{\circ}$.

$2100 / 05 \quad 204$
$35005 / 0604$
$53005 / 40062724$
$3.5 k .5$


FODTNOTES TD TABLE I

1 Beer (19\$1).

2 Paxton (19:0).

3 Dberg (1981).

4SIPRI (1982,1939).

5 Arkin et 2!. (1984).

6 Tromp and LaRoLaue (1982).

$>$ JoffE (1981\%.

3 Lunn (1992).

3 Excluding a sirrilar number of support airerafts.

10 Range atout $2800 \mathrm{~km}$ (any target in su) (Faxton, 1980).

11 Excluding patrol boats and other minor wessels.

12 some of Which belongs to the 139.

12 Excluding spare or reload warheads.

14 The number following the Elash pertains to weapons stationed in WE (for US) or EE (for, כUj.

15 some may be ineluded under short rarige.

15 Some deployed in WE (for US) or EE (for SIJ) (SIPRI, 1978).

us=united states, uJEujestern Europe, EE=Eastern Europe, sU=souiet. Union and $\mathrm{C}=\mathrm{China}$. 


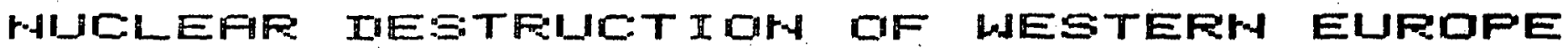

Ir arbitrary units:

CAPAEILITIY DF ENEMYY

TO CARRY THRDISH RN FGSFIJLT IEESITE IEEFENSE EFFORTS

IHTENTTIOHS DF EHENY' ¿ CHFHICE PEP IDHIT TIME THAT AH RGSFULT WILL BE ATTEMPTED?

100

G

10

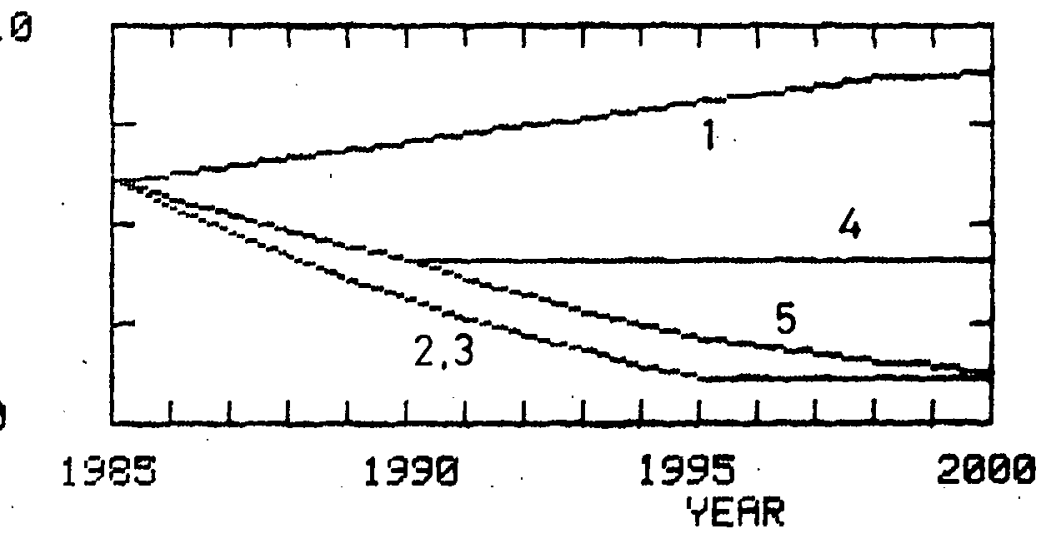

In arbitrany units:

MEASIJRE DF SECURIT'T COHE DUER PRDIUCT DF EAPRBILITY AHI IHTEHT)

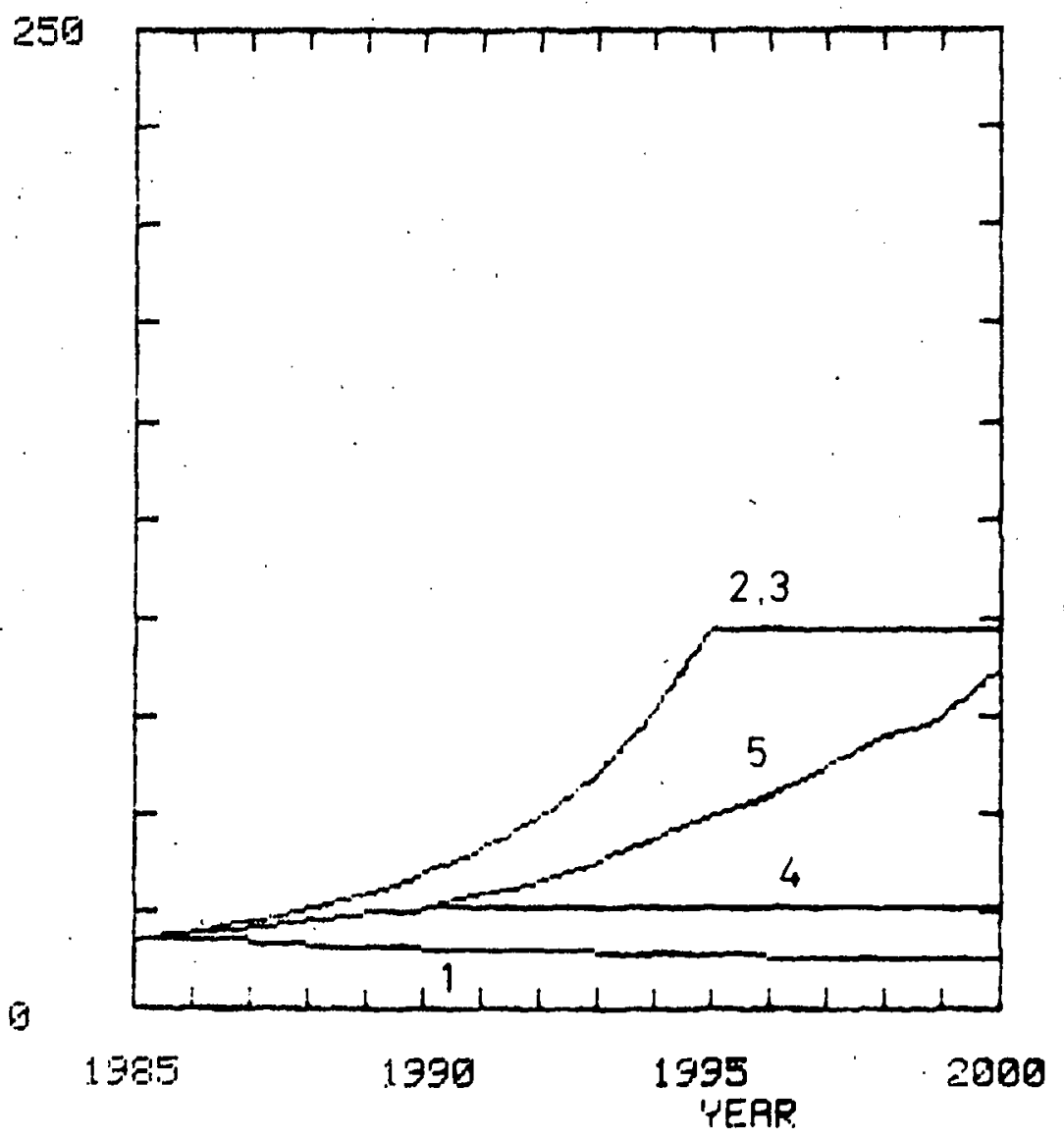

FIG. 1 Humbers refer to Ecenarios 
In arbitrary units:

CAPABILITY OF EHEMY TO CAREYY THPOUSH FN AGSFIJLT IESPITE DEFEHSE EFFIRTS

IHTEHTIONS DF EHEMY

C CHANICE PER UNIT

TIME THAT AN FESFIJLT

HILL BE ATTEMPTED?

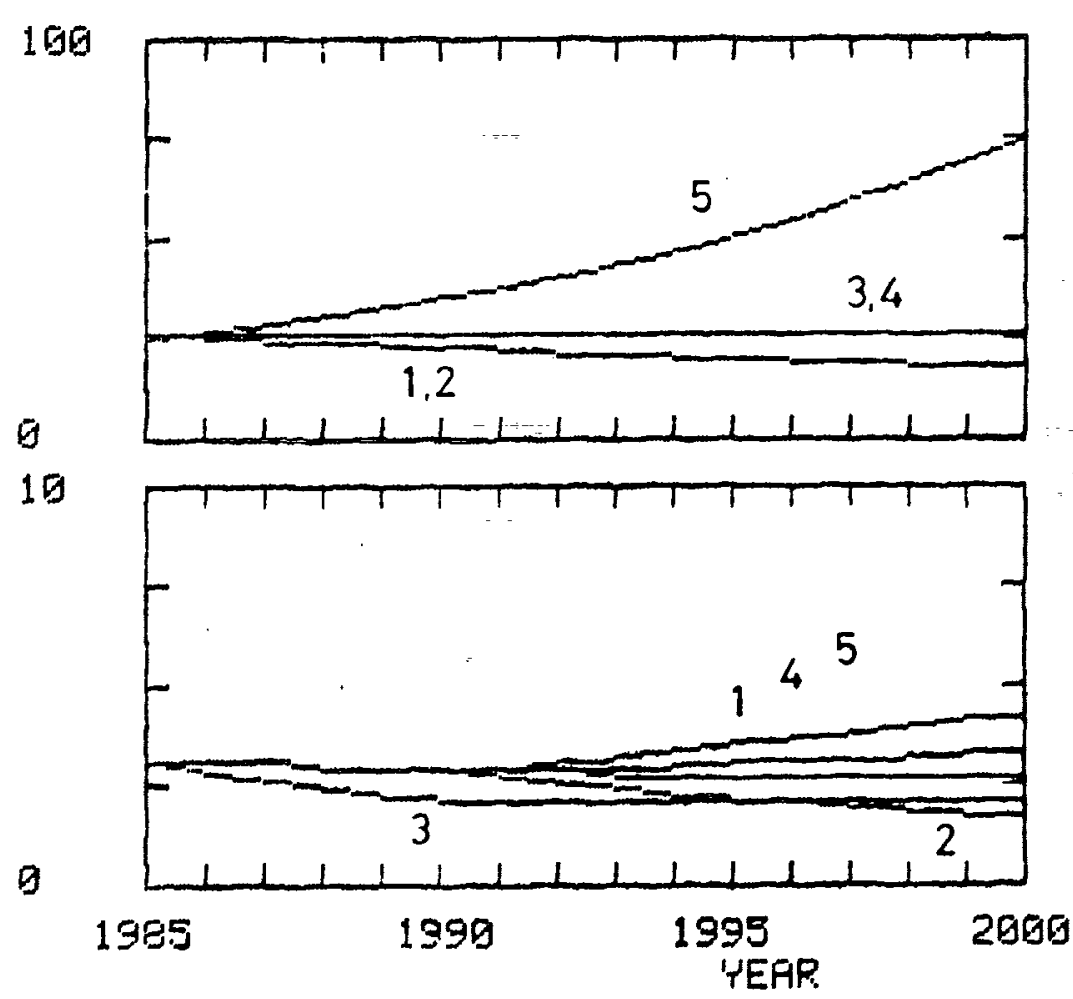

In arbitrary units:

MEASURE OF GECIJITT'Y COHE OUER PROIUUCT OF CAPABILITY FHIS INTEHT)

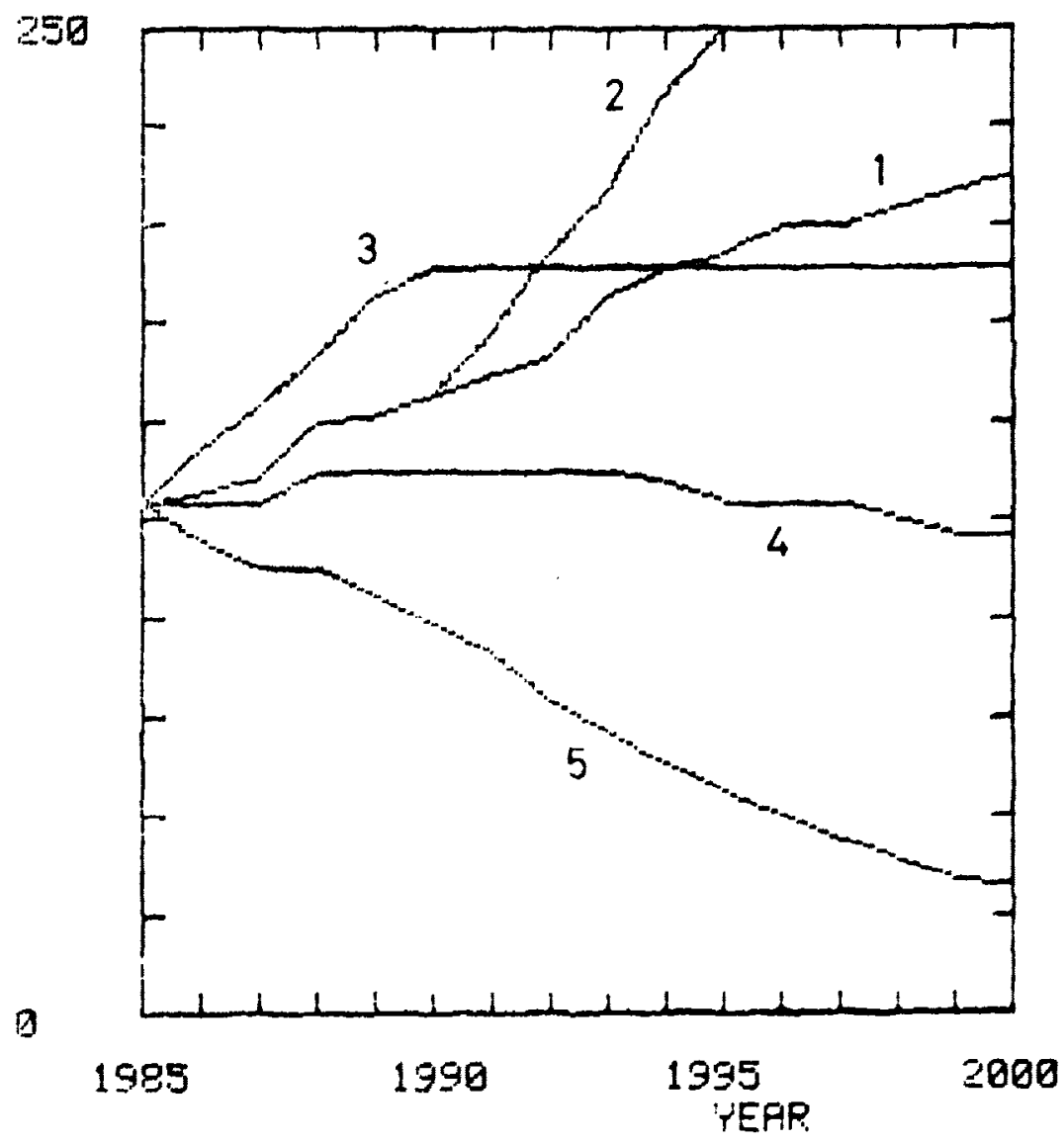

FIG. 2 Humbers refer to scenarios 
1/78 "TANKER OM EN PRAKSIS" - et matematikprojekt.

Projektrapport af Anne Jensen, Lena Lindenskov, Marianne Kesselhahn og Nicolai Lomholt.

Vejleder: Anders Madsen.

2/78 "OPTIMERING" - Menneskets forøgede beherskelsesmuligheder af natur og samfund.

Projektrapport af Tom J. Andersen, Tommy R. Andersen, Gert Kreinee og Peter H. Lassen.

Vejleder: Bernhelm Booss.

3/78 "OPGAVESAMLING", breddekursus $i$ fys $i k$.

Lasse Rasmussen, Aage Bonde Kræmmer, Jens Hojgaard Jensen.

4/78, "TRE ESSAYS" - om matematikundervisning, matematiklæreruddannelsen og videnskabsrindalismen.

Mogens Niss.

5/78 "BIBL IOGRAFISK VEJLEDNING til studiet af DEN MODERNE FYSIKS HISTORIE".

Nr. 3 er a jour fort $i$ marts 1984

Nr. 4 er p.t. udgået.

Nr. 5 er p.t. udgået.

Helge Kragh.

6/78 "NOGLE ARTIKLER OG DEBATINDLFG OM - læreruddannelse og undervisning i. fysik, og - de naturvidenskabelige fags situation efter studenteroproret".

Karin Beyer, Jens Højgaard Jensen og Bent C. Jørgensen.

7/78 "MATEMATIKKENS FORHOLD TIL SAMFUNDSØKONOMIEN".

Nr. 7 er udgået.

8/78 "DYNAMIK OG DIAGRAMMER". Introduktion til energy-bound-graph formalismen.

Peder Voetmann Christiansen.

9/78 'OM PRAKSIS' INDFLYDELSE PA MATEMATIKKENS UDVIKLING". - Motiver til Kepler's:"Nova Stereometria Doliorum Vinarioum".

Projektrapport af Lasse Rasmussen.

Vejleder: Anders Madsen.

10/79 "TERMODYNAMIK I GYMNASIET".

Projektrapport af Jan Christensen og Jeanne Mortensen.

Vejledere: Karin Beyer og Peder Voetmann Christiansen.

$11 / 79$ "STATISTISKE MATERIALER"

red. Jorgen Larsen

12/79 "LINEARE DIFFERENTIALLIGNINGER OG DIFFERENTIALLIGNr. 12 er udgået NINGSSYSTEMER".

Mogens Brun Heefelt

13/79 "CAVENDISH'S FORSEG I GYMNASIET". Projektrapport af Gert Kreinøe.

Vejleder: Albert Chr. Paulsen 
14/79 "BOOKS ABOUT MATHEMATICS: His tory, Philosophy, Education, Models, System Theory, and Works of Reference etc. A Bibliography".

Else Høyrup.

15/79 "STRUKTUREL STABILITET OG KATASTROFER $i$ systemer $i$ og udenfor termodynamisk ligevægt".

Specialeopgave af Leif S. Striegler.

Vejleder: Peder Voetmann Christiansen.

16/79 "STATISTIK I KREFTFORSKNINGEN".

Projektrapport af Michael 01sen og Jorn Jensen.

Vejleder: Jorgen Larsen.

17/79 "AT SPQRGE OG AT SVARE i fysikundervisningen". Albert Christian Paulsen.

18/79 "MATHEMATICS AND THE REAL WORLD", Proceedings of an International Workshop, Roskilde University Centre, Denmark, 1978. Preprint.

Bernhelm Booss \& Mogens Niss (eds.).

19/79 "GEOMETRI, SKOLE OG VIRKEL IGHED".

Projektrapport af Tom J. Andersen, Tommy R. Andersen og Per H.H. Larsen.

Vejleder: Mogens Niss.

20/79 "STATISTISKE MODELLER TIL BESTEMMELSE AF SIKRE DOSER FOR CARCINOGENE STOFFER"

Projektrapport af Michael 01 sen og Jorn Jensen.

Vejleder: Jorgen Larsen.

21/79 "KONTROL I GYMNASIET - FORMRL OG KONSEKVENSER".

Projektrapport af Crilles Bacher, Per S. Jensen, Preben Jensen og Torben Nysteen.

22/79 "SEMIOTIK OG SYSTEMEGENSKABER (1)".

T-port lineært response og støj $i$ fysikken.

Peder Voetmann Christiansen.

23/79 "ON THE HISTORY OF EARLY WAVE MECHANICS - with special emphasis on the role of realitivity".

24/80 "MATEMATIKOPFATTELSER HOS 2.G'ERE"

$a+b$ 1. En analyse. 2. Interviewmateriale. Nr. $24 a+b$ er p.t. udgået.

Projektrapport af Jan Christensen og Knud Lindhardt Rasmussen.

Vejleder: Mogens Niss.

25/80 "EKSAMENSOPGAVER", Dybdemodu let/fysik 1974-79.

26/80 "OM MATEMATISKE MODELLER".

En projektrapport og to artikler.

Jens Hojgaard Jensen m.fl.

27/80 "METHODOLOGY AND PHILOSOPHY OF SCIENCE IN PAUL DIRAC'S PHYSICS".

Helge Kragh.

28/80 "DIELEKTRISK RELAXATION - et forslag til en ny model bygget pa vaskernes viscoelastiske egenskaber" .

Projektrapport, speciale $i$ fysik, af Gert Kreinøe.

Vejleder: Niels Boye 0lsen.
Nr. 14 er p.t. udgået. 
29/80 "ODIN - undervisningsmateriale til et kursus i differentialligningsmodeller".

Projektrapport af Tommy R. Andersen, Per H.H. Larsen og Peter H. Lassen.

Vejleder: Mogens Brun Heefelt

30/80 "FUSIONSENERGIEN - - - ATOMSAMFUNDETS ENDESTATION". oluf Danielsen.

31/80 "VIDENSKABSTEORETISKE PROBLEMER VED UNDERVISNINGSSYSTEMER BASERET PA MENGDELERE".

Projektrapport af Troels Lange og Jorgen Karrebæk.

Vejleder: Stig Andur Pedersen.

32/80 "POLYMERE STOFFERS VISCOELASTISKE EGENSKABER - BELYST VED HJELP AF MEKANISKE IMPEDANSMALINGER OG MOSSBAUEREFFEKTMAL I NGER"

Projektrapport, speciale i fysik, af Crilles Bacher og Preben Jensen.

Vejledere: Niels Boye 01sen og Peder Voetmann Christiansen.

33/80 "KONSTITUERING AF FAG INDEN FOR TEKNISK-NATURVIDENSKABEL IGE UDDANNELSER. I-II" .

Arne Jakobsen.

34/80 "ENVIRONMENTAL IMPACT OF WIND ENERGY UTILIZATION". ENERGY SERIES NO.T.

Bent Sorensen.

Nr. 34 er udgået.

Publ. i "Renewable Sources of Energy and the Environiment", Tycooli International Press, Dublin, 1981.

35/80 "HISTORISKE STUDIER I DEN NYERE ATOMFYSIKS UDVIKLING". Helge Kragh:

36/80 "HVAD ER MENINGEN MED MATEMATIKUNDERVISNINGEN ?". Fire artikler. Mogens Niss.

37/80 "RENEWABLE ENERGY AND ENERGY STORAGE". ENERGY SERIES NO.2.

Bent Sorensen.

38/81 "TIL EN HISTORIETEORI OM NATURERKENDELSE, TEKNOLOGI OG SAMFUND"

Projektrapport af Erik Gade, Hans Hedal, Henrik Lau og Finn Physant.

Vejledere: Stig Andur Pedersen, Helge Kragh og Ib Thiersen.

39/81 "TIL KRITIKKEN AF VEKSTØKONOMIEN" Jens Højgaard Jensen.

40/81 "TELEKOMMUNIKATION I DANMARK - oplæg til en teknologivurdering".

Projektrapport af Arne Jorgensen, Bruno Petersen og Jan Vedde.

Vejleder: Per Norgaard.

41/81 "PLANNING AND POLICY CONSIDERATIONS RELATED TO THE INTRODUCTION OF RENEWABLE ENERGY SOURCES INTO ENERGY SUPPLY SYSTEMS".

ENERGY SERIES NO.3.

Bent Sorensen.
Nr. 30 er udgået.

Udkommer medio 1982 på Fysik-, Matematik- og Kemilærernes forlag.

Nr. 31 er p.t. udgået
Nr. 38 er p.t. udgået

Nr. 40 er p.t. udgået 
42/81 "VIDENSKAB TEORI SAMFUND - En introduktion til materialistiske videnskabsopfattelser".

Helge Kragh og Stig Andur Pedersen.

43/81 1. "COMPARATIVE RISK ASSESSMENT OF TOTAL ENERGY SYSTEMS".

2. "ADVANTAGES AND DISADVANTAGES OF DECENTRALIZATION". ENERGY SERIES N0.4.

Bent Sorensen.

44/81 "HISTORISK UNDERSפGELSE AF DE EKSPERIMENTELLE FORUDSETNINGER FOR RUTHERFORDS ATOMMODEL".

Projektrapport af Niels Thor Nielsen.

Vejleder: Bent $C$. Jorgensen.

$45 / 82$

46/82 "EKSEMPLARISK UNDERVISNING OG FYSISK ERKENDELSE -

I+I I ILLUSTRERET VED TO EKSEMPLER".

Projektrapport af Torben 0. 01sen, Lasse Rasmussen og Niels Dreyer Sorensen.

Vejleder: Bent C. Jargensen.

47/82 "BARSEBACK OG DET VERST OFFICIELT-TANKELIGE UHELD". ENERGY SERIES N0.5.

Bent Sorensen.

48/82 "EN UNDERSOGELSE AF MATEMATIKUNDERVISNINGEN PÅ ADGANGSKURSUS TIL KOBENHAVNS TEKNIKUM" .

Projektrapport af Lis Eilertzen, Jorgen Karrebæk, Troels Lange, Preben Norregaard, Lissi Pedersen, Laust Rishøj, Lijl Røn, Isac Showiki.

Vejleder: Mogens Niss.

49/82 "ANALYSE AF MULTISPEKTRALE SATELLITBILLEDER".

Projektrapport af Preben Norregaard.

Vejledere: Jorgen Larsen \& Rasmus ole Rasmussen.

50/82 "HERSLEV - MULIGHEDER FOR VEDVARENDE ENERGI I EN LANOSBY". ENERGY SERIES N0.6.

Rapport af Bent Christensen, Bent Hove Jensen, Dennis B. Møller, Bjarne Laursen, Bjarne Lillethorup og Jacob Morch Pedersen.

Vejleder: Bent Sorensen.

51/82 "HVAD KAN DER GØRES FOR AT AFHJELPE PIGERS BLOKERING OVERFOR MATEMATIK?"

Projektrapport af Lis Eilertzen, Lissi Pedersen, Lill Ron og Susanne Stender.

52/82 "DESUSPENSION OF SPLITTING ELLIPTIC SYMBOLS"

Bernhelm Booss \& Krzysztof Wojciechowski.

53/82 "THE CONSTITUTION OF SUBJECTS IN ENGINEERING EDUCATION".

Arne Jakobsen \& Stig Andur Pedersen.

54/82 "FUTURES RESEARCH" - A Philosophical Analysis of Its Subiect-Matter and Methods.

Stig Andur Pedersen \& Johannes Witt-Hansen. 

Univers i tetsbibliotek.

En bibliografi.

Else Hoyrup.

56/82 "ÉN - TO - MANGE" -

En undersogelse af matematisk okologi.

Projektrapport af Troels Lange.

Vejleder: Anders Madsen.

57/83 "ASPECT EKSPERIMENTET" -

Skjulte variable $i$ kvantemekanikken?

$\mathrm{Nr} .57$ er udgået.

Projektrapport af Tom Juul Andersen.

Vejleder: Peder Voetmann Christiansen.

58/83 "MATEMATISKE VANDRINGER" - Mode lbetragtninger over spredning af dyr mellem smabiotoper $i$ agerlandet .

Projektrapport af Per Hammershøj Jensen \&

Lene Vayn Rasmussen.

Vejleder: Jorgen Larsen.

59/83 "THE METHODOLOGY OF ENERGY PLANNING".

ENERGY SERIES NO. 7.

Bent Sorensen.

60/83 "MATEMATISK MODEKSPERTISE" - et eksempel.

Projektrapport af Erik 0. Gade, Jorgen Karrebæk og Preben Norregaard.

Vejleder: Anders Madsen. .

61/83 "FYSIKS IDEOLOGISKE FUNKTION", som et eksempel pa en naturvidenskab - historisk set.

Projektrapport af Annette Post Nielsen.

Vejledere: Jens Høyrup, Jens Højgaard Jensen og Jargen Vogelius.

62/83 "MATEMATISKE MODELLER" - Litteratur på Roskilde

Universitetsbibliotek.

En bibliografi. 2. rev. udgave

Else Høyrup

63/83 "CREATING ENERGY FUTURES: A SHORT GUIDE TO ENERGY PLANNING"

ENERGY SERIES No. 8

David Crossley \& Bent Sorensen

64/83 "VON MATHEMATIK UND KRIEG".

Bernhelm Booss og Jenș Hoyrup

65/83 "ANVENOT MATEMATIK - TEORI ELLER PRAKSIS".

Projektrapport af Per Hedegard Andersen, Kirsten Habekost, Carsten Holst-Jensen, Annelise von Moos, Else Marie Pedersen, Erling Moller Pedersen.

Vejledere: Bernhelm Booss \& Klaus Grübaum

66/83 "MATEMATISKE MODELLER FOR PERIODISK SELEKTION I ESCHERICHIA COLI".

Projektrapport af Hanne Lisbet Andersen, Ole Richard Jensen og Klavs Frisdahl.

Vejledere: Jørgen Larsen og Anders Hede Madsen 
67/83 "ELIPSOIDE METODEN - EN NY METODE TIL LINEER PROCRAMMERING?"

Projektrapport af Lone Biilmann og Lars Boye Vejleder: Mogens Brun Heefelt

68/83 "STOKASTISKE MODELLER I POPULATIONSGENETIK" - til kritikken af teoriladede modeller.

Projektrapport af Lise Odgård Gade, Susanne Hansen, Michael Hviid, Frank Molgård 01 sen.

Vejleder: Jorgen Larsen.

69/83 "ELEVFORUDSATNINGER I FYSIK"

- en test i l.g med kommentarer

Albert Chr. Paulsen

70/83 "INDLERINGS- OG FORMIDLINESPROBLEMER I MATEMATIK PA VOKSENUNDERVISNINGSNIVEAU"

Projektrapport af Hanne Lisbet Andersen, Torben J. Andreasen, Svend Age Houmann, Helle Glerup Jensen, Keld Fl. Nielsen, Lene Vagn Rasmussen.

Vejleder: Klaus Grünbaum \& Anders H. Madsen

71/83 "PIGER OG FYSIK"

- et problem og en udfordring for skolen?

Karin Beyer, Sussanne Blegaa, Birthe 0lsen, Jette Reich \& Mette Vedelsby

72/83 "VERDEN IFøLGE PEIRCE" - to metafysiske essays, om og af C.S. Peirce.

Peder Voetmann Christiansen

73/83 "EN ENERGIANALYSE AF LANDBRUG"

- okologisk contra traditionelt

ENERGY SERIES No. 9

Specialeopgave $i$ fysik af Bent Hove Jensen

Vejleder: Bent Sorensen

74/84 "MINIATURISERING AF MIKROELEKTRONIK" - om videnskabeliggjort teknologi og nytten af at lære fysik

Projektrapport af Bodil Harder og Linda Szkotak Jensen.

Vejledere: Jens Højgaard Jensen og Bent $C$. Jørgensen

75/84 "MATEMATIKUNDERVISNINGEN I FREMTIDENS GYMNASIUN" - Case: Lineær programmering

Projektrapport af Morten Blomhø.j, Klavs Frisdah1, Frank Molgaard 01 sen

Vejledere: Mogens Brun Heefelt \& Jens Bjørneboe

76/84 "KERNEKRAFT I DANMARK?" - Et heringssvar indkaldt af miljoministeriet, med kritik af miljostyrelsens rapporter af 15. marts 1984.

ENERGY SERIES No. 10

Af Niels Boye 01 sen og Bent Sorensen

77/84 "POLITISKE INDEKS - FUP ELLER FAKTA?"

Opinionsundersøgelser belyst ved statistiske modeller

Projektrapport af Svend Age Houmann, Keld Nielsen, Susanne Stender

Vejledere: Jorgen Larsen \& Jens Bjorneboe 
78/84 "JEVNSTRGMSLEDNINGSEVNE OG GITTERSTRUKTUR I AMORFT GERMANIUM"

Specialerapport af Hans Hedal, Frank C. Ludvigsen og Finn $C$. Physant

Vejleder: Niels Boye 01sen

79/84 "MATEMATIK OG ALMENDANNELSE"

Projektrapport af Henrik Coster, Mikael Wennerberg Johansen, Povl Kattler, Birgitte Lydholm og Morten Overgaard Nielsen.

Vejleder: Bernhelm Booss

80/84 "KURSUSMATERIALE TIL MATEMATIK B"

Mogens Brun Heefelt

81/84 "FREKVENSAFHFNGIG LEDNINGSEVNE I AMORFT GERMANIUM" Specialerapport af Jorgen Wind Petersen og Jan Christensen

Vejleder: Niels Boye 01 sen

82/84 "MATEMATIK- OG FYSIKUNDERVISNINGEN I DET AUTOMATISEREDE SAMFUND"

Rapport fra et seminar afholdt i Hvidovre

25-27 april 1983

Red.: Jens Højgaard Jensen, Bent C. Jørgensen og Mogens Niss

83/84 "ON THE QUANTIFICATION OF SECURITY"

PEACE RESEARCH SERIES NO. 1

af Bent Sorensen

84/84 "NOGLE ART IKLER OM MATEMATIK, FYSIK OG ALMENDANNELSE". Jens Hojgaard Jensen, Mogens Niss m. fl.

85/84 "CENTRIFUGALREGULATORER OG MATEMATIK"

Specialerapport af Per Hedegård Andersen, Carsten HolstJensen, Else Marie Pedersen og Erling Møller Pedersen

Vejleder: Stig Andur Pedersen

86/84 "SECURITY IMPLICATIONS OF ALTERNATIVE DEFENSE OPTIONS FOR WESTERN EUROPE"

PEACE RESEARCH SERIES NO. 2

af Bent Sorensen

87/84 "A SIMPLE MODEL OF AC HOPPING CONDUCTIVITY IN DISORDERED SOLIDS"

af Jeppe C. Dyre 
ISSN 0106-6242 